\title{
COMMITMENT TO CHURCH OF THE POOR IN SERVICE AT THE CINTA ORANG MISKIN FOUNDATION, SURABAYA
}

\author{
Saefnat Saetban 1) Agustinus Faot ${ }^{2)}$ \\ 1) Evangelical Theological Seminary of Indonesia - Surabaya \\ E-mail: saefnatsaetban@sttii-surabaya.ac.id \\ 2) Evangelical Theological Seminary of Indonesia - Surabaya \\ E-mail:agustinusfaot@sttii-surabaya.ac.id
}

\begin{abstract}
Research on the commitment of the poor at the Cinta Orang Miskin Foundation is motivated by the reality of academic and practical gaps. From an academic perspective, researchers have never found the commitment of the poor at the Cinta Orang Miskin Foundation, even though the number of poor people is committed for the church to thrive. Currently the number reaches 1,300 people. ${ }^{1}$ On a practical level, this research wants to explore the decisions of these poor people to find out their commitment to involvement in the Cinta Orang Miskin Foundation (COM), which is served by Pastor Gunawan Setiadarma in Surabaya, East Java, which has experienced significant growth from 23 congregations to 1,300 people.

The problem of poverty is a problem that is being faced by the nation (nations in the world in general. The Indonesian nation itself cannot be separated from the poverty problem. The economic crisis that occurs within the Indonesian nation has an impact on all aspects of people's lives. It can be seen from the existence of people who live in poverty, live in slum environments, and the number of children (street children who are scattered in cities (cities in Indonesia). During this economic crisis, the number of street children in Indonesia increased drastically.
\end{abstract}

Keywords: people, church,committed.

\section{INTRODUCTION}

Building a congregational life commitment in church is not an easy thing, because some congregations like to switch churches. They enjoy all the facilities, events and services of several churches. The motivation of congregants who like to change churches is for their own pleasure, and sees praise as nothing more and a show, some just want to experiment, some try to find a church that suits their wishes, some think all churches are the same, as a result congregations like this tend to be unfaithful to the church. The congregation feels bored of worshiping

\footnotetext{
${ }^{1}$ Wawancara dengan Gunawan Setiadarma
} 
in one church because worship only runs as a routine that is done every week, the congregation feels they have nothing in the church. They consider worship as nothing more and an obligation and routine. This saturation eventually led them to leave the church. ${ }^{2}$ The above quotation can explain that commitment is not easy for every church that is served. Because congregants in the melenial era prefer to change churches, prefer to be in a church that is luxurious, comfortable, the place is pleasant, but there are also congregations who just want to try the atmosphere of worship in a neighboring church. With the aim of getting the atmosphere of worship in accordance with his wishes. So that the congregation is not faithful in worshiping or in carrying out other forms of service. Congregations tend to view worship as an obligation and routine only so this thought leads the congregation to saturation.

Church leaders can encourage congregations to have a church commitment in the local church by: arousing enthusiasm for Sunday worship, building fellowships, congregational visitations, providing counseling services, conducting congregational training, guiding congregations to serve, and

\footnotetext{
${ }^{2}$ Sugianto, Jurnal Membangun Komitmen Hidup Jemaat Dalam Bergereja.(Jawa Timur: Lawang,
}

forming cell groups. God wants every believer to remain faithful to Christ and His church. Because Christ remains committed to His church, willingly died for His church. The church as a home for life means that when members of the congregation have matured in faith and have a good knowledge of God's Word, they will live as whole and growing Christians.

$\mathrm{He}$ is also willing to accept responsibility for upbuilding other church members. Continuous regeneration is done and occurs in the church. All of these are ways that can be used to build up church members to have a church commitment.In the explanation above, it can be stated that the leader of a church or an organization should be able to provide a strong impetus for the congregation to have a committed life by doing passionate ways for the congregation, so in this case, there are several forms of service that can be used, namely: building. fellowship with the congregation, serving the congregation consistently, guiding the congregation to serve to form cell groups to mature the congregation.

The teaching principle presented above would like to emphasize that having to convince the congregation of that

2011), 8 . 
commitment is a very basic thing in the Christian faith. Because Jesus Christ did his ministry with true commitment, everyone who believes in Him is obliged to imitate the commitment that the Lord Jesus made.

Second, commitment is understood as a responsibility. The writing ideas that are raised in this section, of course, want to formulate that commitment is the responsibility. We become Christians by accounting for our lives to Christ, but we can only become members of God's family by accounting for our lives to other Christians. Since the church is God's family, it is very important for us to become members of the local church. The difference between "immigrants" and "members" of the church can be seen in one word: COMMITMENT. ${ }^{3}$ Based on the quote above, it can explain that every believer must be able to commit to what he believes.

Characteristics of adult life can be seen from their commitment to worship at a local church or a foundation. A successful life, a good life, a godly Christian life demands more than a contribution, even though every contribution is valuable. Ultimately it requires a commitment - a whole-souled, held fast, eternally honored commitment to principles which we know are true in the commandments God has given. This quote can emphasize the previous section that a committed person in an organization must do everything with all his soul, thus it can be said that he is successful in a committed life. The forms of commitment described in the following quotations are: Commitment to God (obedient to God, Willing to serve God for life) Commitment to family - Commitment to the Church (faithful to the local church, caring for church growth) - Commitment to work - Commitment in the State. ${ }^{4}$

The third commitment is proof of life as a Christian. The act closest to commitment is loyalty. Loyal literally means loyalty and loyalty is defined as loyalty. In general, loyalty can be defined as someone's loyalty to something or certain services. This loyalty is something that arises without coercion but comes from one's own awareness. In the past, the efforts made to create customer satisfaction tended to influence customer attitudes, while the concept of customer loyalty emphasized behavior rather than attitude. In fact, in the market, many customers are

\footnotetext{
${ }^{3}$ Max Jukes, The Importance Of Churches, (New York, 2015)160.
}

\footnotetext{
${ }^{4}$ Jonathan Edward, Total Commitment (Solo: Yayasan Lembaga Sabda, 2012), 54.
} 
satisfied with the product offered but can switch to another product under certain conditions, that is what is defined as being satisfied but not loyal. loyalty is sincerity, not breaking promises or betraying, struggling and grace, and maintaining love and keeping promises together.

Loyalty between husband and wife must include loyalty to the little things that exist in their life. So that both of them can live a life filled with love, affection, respect and sincerity in their hearts, not to hurt each other. loyalty means struggle, grace, sacrifice, and patience. Based on some of the definitions of consumer loyalty above, it can be explained to be consumer loyalty which is represented in consistent purchases of products or services over time and there is a good attitude to recommend other people to buy the product. An indication of true loyalty requires a measure of attitude combined with a measurement of behavior. ${ }^{5}$

The fourth can be seen from the ministry in this section, the author is based on the observation that the Cinta Orang Miskin Foundation (COM), Gunawan Setia darma, has committed to providing holistic service to the congregation in the Cinta Orang Miskin Foundation, and this

\footnotetext{
${ }^{5}$ Howard W. Hunter, Ajaran-Ajaran Pemimpin Gereja, 2018, hal 19.
}

ministry is very developed, with the addition of souls.

Because this foundation believes that holistic service is a part of believers who have a committed life. The traditional view sees mission as identical (and limited to) evangelism. According to the modern view (liberals) mission includes evangelism and social service, but for them evangelism is not more important than social service. The evangelical paradigm shift regarding the notion of mission was pioneered by John Stott. He argues that biblical mission includes evangelism and ministry, but evangelism remains intimate.

\section{RESEARCH METHOD}

In this writing, the researcher uses quantitative research methods which are a form of correlational or relationship between one variable and another. A research variable is an attribute or nature or aspect of a person or object that has certain variations and is applied by research to be studied so as to produce a conclusion in a study. ${ }^{6}$ One of the authors, Arikunto, also emphasized that variables are the object of research or what is the point of attention of a study. In addition, Azwar also revealed that variables are concepts concerning the

\footnotetext{
${ }^{6}$ Sugiyono, Metode Penelitian Kuantitafi Kualitatif dan $R \& D$ (), 38 .
} 
attributes or traits contained in the research subject that can vary quantitatively or qualitatively. $^{7}$

This type of qualitative research has two kinds of variables, namely: The prediction variable which is used to predict changes in one variable and the criterion, which changes according to changes in the prediction variable. ${ }^{8}$ Every time there is a change in the prediction variable, the criteria variable also changes. This opinion was expressed by Azwar. Correlation research is research that has a relationship between variables. Two or more variables are examined to see the relationship that occurs between them without trying to change or treat these variables.

\section{RESULTS AND DISCUSSION}

In this chapter, the researcher will present the results of the research on the Commitment to Church of the Poor in Service at the Cinta Orang Miskin Foundation, Surabaya.

\section{Research variable}

Based on the above opinion, the variables are: Commitment to the church (X) Servants at the Love for the Poor Foundation (Y). X is the independent variable (independent variable), which becomes the emergence of a change and can affect variables that affect others. Meanwhile, $\mathrm{Y}$ is the dependent variable, namely the variable that is the result of the independent variable.

\footnotetext{
${ }^{7}$ Arikunto Suharsimi, Prosedur Penelitian Suatu Penedekatan Praktik, (Jakarta: PT. Rineka Cipta, 2006), 118
}

\section{Simple Regression Test Between X And Y}

The simple regression test serves to predict the value of the $Y$ variable if the variable value is at zero or if the $\mathrm{X}$ variable is added several times, then the assumption needed for this analysis is the normality test. The normality test is needed to find out whether the data collected from each dependent and independent variable both have a normal distribution or not after conducting a regression test through SPSS, the results are shown in the following tables:

\section{Model Summary}

\begin{tabular}{|r|c|c|c|c|}
\hline Model & & & $\begin{array}{c}\text { Std. } \\
\text { Error } \\
\text { of the } \\
\text { Estima } \\
\text { te }\end{array}$ \\
\hline 1 1,596 & $\mathrm{R}$ & $\begin{array}{c}\text { Rquare } \\
\text { Squasted } \\
\mathrm{R} \\
\text { Square }\end{array}$ &, 332 & 4,039 \\
\hline
\end{tabular}

a. Predictors: (Constant), $\mathrm{X}$

Based on the results of the analysis of the table above (Model Summary), it is known that the correlation between the work commitment of the poor in the services of the Cinta Orang Miskin Foundation (COM), Surabaya, is in accordance with the results of the correlation, which can be calculated with the $r$ value of 0.596 .

Value The commitment to church of the poor in the Services of the Poor People Foundation (COM), Surabaya, is quite strong because it is greater than $(>0.355)$, this shows that it has a positive value so that commitment has a relationship and

\footnotetext{
${ }^{8}$ Saifuddin Azwar,Metode Penelitian (Tk: tp, $\mathrm{tt}$ ), 59.
} 
increasingly triggers poor people to serve.The conclusion from the table above explains that simple regression is well received, getting a sig value, $0.001<0.05$, so $\mathrm{H} 1$ is accepted in other words that there is a relationship between Church Commitment of the Poor in Service at the Cinta Orang Miskin Foundation (COM), Surabaya.

\section{Dependent Variable: $Y$}

From the table above, it can be seen that the results of simple regression analysis are as follows: The constant is 23,507 ; that is, Y is 23,507 . The regression coefficient $\mathrm{X}$ is 0 , $474 \mathrm{Y}=23,507+0,474$ This means that the value of $Y=23,507$ and the value of $X=0$, 474 So it can be concluded that Variable $X$ has a strong enough relationship of 0.474 to variable Y.

\section{CONCLUSION}

Based on the results of data management and discussion that has been carried out, the researcher will conclude the results of the research regarding the commitment of the poor people church to the Services of the Love the Poor Foundation (COM) in Surabaya. The conclusions of this study are as follows:

So based on the results of research tested through SPSS, validity testing was carried out to determine which questionnaire statements were valid and to be used in this study, and the validity results found 10 valid $X$ statements and 10 valid $Y$ statements because of the test results. the validity of all totals of all totals is greater than the provision of $r$ table of 0.361 . After the validation test, the reliability test was carried out and the reliability test results were carried out, namely the Cronbach's Alpha value of variable $\mathrm{X}$ was 0,714 and Cronbach's Alpha variable Y was 0.686, both of which were greater than the provisions, then it was declared reliable. The results of the Correlation Test and Correlation Test, namely the variables $\mathrm{X}$ and $\mathrm{Y}$ have a strong enough relationship, based on the results of the $\mathrm{X}$ and $\mathrm{Y}$ correlation test, the value of 0.596 is included in the moderate / strong correlation scale, namely the interval between (0.21$0.599)$.

So it can be concluded that these two variables have a strong enough relationship. With the results of the correlation test between service in foundations $(\mathrm{X})$ and church commitment (Y), both have a responsible relationship. After seeing the relationship between the two variables, to see how strong the relationship between the variables $\mathrm{X}$ and $\mathrm{Y}$ is, a simple regression test is carried out and based on the results of a simple regression test, the Coefficients Variable $\mathrm{X}$ value is 0,474 , so it can be concluded that the relationship is 0,474 which can be related with variable $\mathrm{Y}$, while 23, 507, from variable $\mathrm{Y}$ has a relationship with other factors. After the simple regression test, a Hypothesis Test is performed, namely the significance value in 
the Coefficients table of 0.000 is stated to be lower than 0.05 so that $\mathrm{HO}$ rejects and accepts H1. So it can be concluded that there is a significant relationship between the commitment to church the Mikisn people in the Services of the Poor People Foundation (COM), Surabaya.

\section{Suggestion}

From the results of research studies in the field, researchers intend to provide suggestions that can be useful for institutions, foundations and other researchers who can carry out the same topic. There are also suggestions related to this topic:

First, future researchers are expected to examine more sources and references related to commitment and be able to broaden their horizons with the ideas that develop this research.

Second, readers are expected to add knowledge about the importance of commitment in organization because without commitment all expectations will never be achieved. The strengths and achievements of an organization must be based on commitment.

Third, the Foundation is expected to further improve effective services because this will increase commitment at a high level, so that the congregation will be more loyal in serving the Cinta Orang Miskin
Foundation (COM), Surabaya.

\section{REFERENCES}

[1]. Sugianto, Jurnal Membangun Komitmen Hidup Jemaat Dalam Bergereja.(Jawa Timur: Lawang, 2011),

[2]. Max Jukes, The Importance of Churches, (New York, 2015)160.

[3]. Howard W. Hunter, Ajaran-Ajaran Pemimpin Gereja, 2018.

[4]. Jonathan Edward, Total Commitment (Solo: Yayasan Lembaga Sabda, 2012).

[5]. John R. W. Stott, Christian Mission in the Modern World (Downer Grove: InterVarsity Press, 1975).

[6]. Herlianto, 1998. Pelayanan Perkotaan (Bandung: Yabina).

[7]. J. D. Bosch, Transformasi Misi Kristen: Sejarah Teologi Misi yang Mengubah dan Berubah. (Jakarta: BPK Gunung Mulia, 1997).

[8]. William Vun. Who is Building Whose Church? (Jakarta: Nafiri Gabriel, 2010).

[9]. Sugiyono, Metode Penelitian Kuantitafi Kualitatif dan $R$ \& D () Arikunto Suharsimi, Prosedur Penelitian Suatu Penedekatan Praktik, (Jakarta: PT. Rineka Cipta, 2006).

[10]. Saifuddin Azwar,Metode Penelitian (Tk: tp, tt). 